\title{
Tetranychus urticae Koch (Acari:Tetranychidae)'nin karanfil popülasyonlarında abamectin ve spirodiclofen'e karşı duyarlılık düzeyleri ${ }^{1}$
}

\author{
Sensitivity levels of Tetranychus urticae Koch (Acari:Tetranychidae) against abamectin and \\ spirodiclofen in clove populations
}

\author{
Sibel YORULMAZ SALMAN ${ }^{*}$
}

Tuğçe KOCAMAN ${ }^{2}$

\begin{abstract}
Tetranychus urticae is a harmful species which causes important economic losses in cut flowers. Sensitivity levels against abamectin and spirodiclofen has been determined by using petri plate-spray tower method in four $T$. urticae populations which was collected from clove greenhouses. It was determined that there was 43.53-246.23 fold resistance against abamectin and 30.49-118.78 fold resistance against spirodiclofen in two spotted spider mite populations. Also, polyacrylamide gel electrophoresis and kinetic reading methods have been applied for the purpose of determining the relationship of resistance development with esterase enzyme. The thickest esterase band of two spotted spider mite populations in electrophoresis gels has been determined in K3 population. Also, 4.48 fold esterase enzyme activities has been found in the same population as the result of kinetic reading of esterase enzyme. These findings indicate that esterase enzyme could be effective in abamectin and spirodiclofen resistance development in clove populations of $T$. urticae.
\end{abstract}

Keywords: Tetranychus urticae, sensitivity, acaricide, esterase

Öz

Tetranychus urticae kesme çiçeklerde önemli ekonomik kayıplara neden olan zararlı bir türdür. Karanfil seralarından toplanan dört adet $T$. urticae popülasyonlarındaabamectin ve spirodiclofen'e karşı duyarlılık düzeyleri petri kabı- ilaçlama kulesi yöntemi kullanılarak belirlenmiştir. İki noktalı kırmızı̈rümcek popülasyonlarında abamectine karşı 43.53-246.23 kat ve spirodiclofen'e karşı 30.49-118.78 kat direnç belirlenmiştir. Ayrıca direnç gelişiminin esteraz enzimi ile olan ilişkisini belirlemek amacıyla poliakrilamid jel elektroforez ve kinetik okuma yöntemleri uygulanmıştır. İki noktalı kırmızıörümcek popülasyonlarının elektroforez jellerinde en kalın esterazbantı K3 popülasyonunda belirlenmiştir. Ayrıca esteraz enziminin kinetik okuması sonucunda aynı popülasyonda 4.48 kat esteraz enzim aktivitesi bulunmuştur. Bu bulgular T. urticae'nin karanfil popülasyonlarında abamectin ve spirodiclofen direnç gelişiminde esteraz enziminin etkisi olabileceğini göstermektedir.

Anahtar sözcükler: Tetranychus urticae, duyarlılık, akarisit, esteraz

\footnotetext{
${ }^{1}$ Bu çalışma TÜBiTAK 2209-A Üniversite Öğrencileri Yurt Içi Araştırma Projeleri Destek Programı tarafından desteklenmiştir

${ }^{2}$ Süleyman Demirel Üniversitesi, Ziraat Fakültesi, Bitki Koruma Bölümü, Isparta

*Sorumlu yazar (Corresponding author) e-mail: sibelyorulmaz@sdu.edu.tr

Alınış (Received): 11.11.2016

Kabul ediliş (Accepted): 05.04.2017

Çevrimiçi Yayın Tarihi (Published Online):03.10.2017
} 


\section{Giriş}

Tetranychus urticae Koch (Acari:Tetranychidae) süs bitkileri ve sera alanlarında ürün kaybına neden olan en önemli tarımsal zararlı akar türlerinden birisidir (Jepson et al., 1975; Bolland et al., 1998). Kırmızıörümcekler emgi sonucunda nekrotik leke oluşumuna, yüksek popülasyonlarda ise yapraklarda kuruma ve dökülmelere neden olurlar. İki noktalı kırmızıörümcek 70 bitki cinsi içerisinde yer alan 1100'den fazla bitki türünde zarar meydana getirmektedir (Grbic et al., 2011). Ülkemizde bu zararlı ile mücadelede genellikle kısa sürede sonuç vermesi sebebiyle akarisitler kullanılmaktadır. Ancak iki noktalı kırmızıörümcek hızlı üreme yeteneği, haplodiploidseksual üreme özelliği ve kısa yaşam döngüsünden dolayı uygulanan birçok akarisite karşı direnç geliştirmiş durumdadır (Nauen et al., 2000; Van Leeuwen et al., 2010). T. urticae, tüm arthropodlar içerisinde pestisit direncinin en yaygın olarak görüldüğü türdür. Kırmızıörümcekler akarisitlere detoksifikasyon metabolizmaları içerisinde yer alan enzimler vasıtasıyla direnç geliştirmektedir (Feyereisen, 1995).

Son yıllarda Isparta ili Merkez ilçede örtü altı kesme çiçek üretim faaliyetleri oldukça yoğun bir şekilde yapılmaktadır. Isparta ili uygun iklimsel ve ekolojik özellikleri nedeniyle örtü altı üretimde önemli bir yere gelmiştir. Antalya iline alternatif olarak yaz döneminde karanfil dikimi nisan sonunda başlayıp ekim sonuna kadar Isparta ilindeki seralarda yapılmaktadır. Isparta ili Merkez ilçede 2014 yılı verilerine göre yaklaşık 51.900 adet plastik sera bulunmakta ve 500 dekarlık alan üzerinde örtüaltı karanfil (Dianthus caryophyllus L.) üretimi yapılmaktadır (Anonymous, 2016). Karanfil üretimi seraları içerisinde ilk sırada kırmızı̈rümcek olmakla beraber thrips [Frankliniella occidentalis (Pergande)] (Thysanoptera:Thripidae) ve yeşilkurt [Heliothis armigera (Hubner)] (Lepidoptera: Noctuidae) önemli zararlara sebep olmaktadır. Bölgedeki üreticiler karanfil üretim seralarında zararlılara karşı ilk sırada kimyasal mücadeleyi tercih etmektedirler. Karanfil seralarında yoğun pestisit uygulamaları sonucunda kırmızıörümceklerin kullanılan akarisitlere karşı direnç geliştirmelerinin olası bir durum olduğu düşünülmektedir.

Çalışmada T. urticae'nin karanfil popülasyonlarında abamectin ve spirodiclofen'e karşı direnç gelişimi ve direncin esteraz enzimi ile olan ilişkisinin incelenmesi amaçlanmıştır.

\section{Materyal ve Yöntem}

\section{Tetranychus urticae popülasyonlarının toplanması ve üretilmesi}

Isparta İli Merkez ilçede bulunan karanfil seralarına 2015 yılı Temmuz ve Ağustos aylarında survey çalışmaları yapılmış ve 4 adet $T$. urticae popülasyonu toplanmıştır. Üzerinde kırmızıörümcek bulunduğu şüphelenilen yaprak örnekleri toplanarak etiketlenmiş ve laboratuara getirilmiştir. T. urticae popülasyonlarınının artmasını sağlamak amacıyla yaprak örnekleri temiz barbunya bitkilerine aktarılarak kültüre alınmıştır. Karanfil seralarından toplanan kırmızıörümcek popülasyon adları, toplanma yerleri ve toplanma tarihleri çizelge 1 'de verilmiştir. Popülasyonlarda direnç oranlarının belirlenmesi amacıyla karşılaştırma popülasyonu olarak T.urticae'nin hassas popülasyonu [German Susceptible Strain (GSS)] kullanılmıştır. Popülasyonlar $26 \pm 1{ }^{\circ} \mathrm{C}$ sıcaklıkta, \% 50-60 orantılı nem ve florasan lambalar ile 16 saat aydınlık, 8 saat karanlık koşulların sağlandığı iklim odalarında yetiştirilmiştir.

Çizelge 1. Tetranychus urticae popülasyonlarının adları, toplanma yerleri ve tarihleri

\begin{tabular}{clc}
\hline Popülasyon Adı & Toplandığı Yer & Toplandığı Tarih \\
\hline K1 & Karanfil serası & 05.07 .2015 \\
K2 & Karanfil serası & 15.07 .2015 \\
K3 & Karanfil serası & 24.07 .2015 \\
K4 & Karanfil serası & 05.08 .2015 \\
\hline
\end{tabular}

\section{Akarisitler}

Isparta ili Merkez İlçe karanfil seralarında kırmızıörümcek mücadelesinde yaygın olarak kullanılan iki akarisit çalışmalarda kullanılmıştır. Toksisite çalışmalarında kullanılmak üzere abamectin (Agrimec EC, Syngenta) ve spirodiclofen (Envidor SC 240, Bayer Crop Science) etkili maddeye sahip akarisitler tercih edilmiştir. Esteraz enziminin belirlenmesi için yapılan biyokimyasal çalışmalarda kullanılan $\alpha$-naphthyl asetat Acros, Bovine Serum Albumine (BSA) ise Amresco firmalarından temin edilmiştir. 


\section{Bioassay testi}

Karanfil seralarından toplanan $T$. urticae popülasyonlarında toksisite denemelerinde petri kabı-ilaçlama kulesi yöntemi kullanıımıştır. Kırmızıörümcek popülasyonlarında LC $_{50}$ değerleri ve direnç oranlarının belirlenmesi için yapılan bioassay çalışmaların tamamında 0-24 saatlik $T$. urticae larvaları kullanılmıştır. $T$. urticae larvalarını elde etmek amacıyla dişi bireyler petri içinde hazırlanan yaprak disklere aktarılmış ve 24 saat sonra bırakılan yumurtalardan çıkan larvalar denemelerde kullanılmıştır. Popülasyonlarda LC $_{50}$ denemeleri sonucunda uygun akarisit dozları belirlenmiştir. Her popülasyon için belirlenen akarisit dozları dikkate alınarak, ilaç konsantrasyonları \%50 seyreltilerek hazırlanmıştır. Denemeler 1 kontrol+7 doz, 3 tekerrür olacak şekilde kurulmuştur. Petri içerisinde hazırlanan yaprak disk üzerine 25 adet 0-24 saatlik akar larvaları aktarılmıştır. Petrilere ilaçlama kulesinde $1 \mathrm{~atm}$ basınç altında yaprak üzerine $2 \mathrm{ml}$ olacak şekilde hazırlanan ilaç konsantrasyonları uygulanmıştır. Kontrol petrilerinde bulunan kırmızı̈rümceklere ise sadece saf su uygulaması yapılmıştır. Petriler içerisinde bulunan kırmızıörümceklerde $L_{50}$ değerinin belirlenebilmesi için ölü-canlı sayımları 7. günde yapılmıştır. Ölü-canlı sayımları dikkate alınarak $T$. urticae popülasyonlarının $L_{50}$ değerleri POLO bilgisayar paket programında (LeOra Software, 1994) hesaplanmıştır. Karanfil seralarından toplanan $T$. uticae popülasyonlarının $\mathrm{LC}_{50}$ değerlerinin hassas popülasyonun $\mathrm{LC}_{50}$ değerine oranlanmasıyla direnç oranları bulunmuştur.

\section{Biyokimyasal testler}

\section{Poliakrilamid jel elektroforez (PAGE) yöntemi}

Tetranychus urticae popülasyonlarında esteraz enziminin görsel olarak incelenebilmesi için kullanılan elektroforez çalışmalarında Goka\&Takafuji (1992) yöntemi kullanıımıştır. Her kırmızıörümcek popülasyonu için 5 adet ergin dişi birey $50 \mu \mathrm{l}$ homojenizasyon tampon içerisinde plastik ezici yardımı ile ezilmiştir. Ezme işleminden sonra elde edilen homojenat her bir jel hücresine $10 \mu$ l olacak şekilde yüklenmiştir. Elektroforez işleminde elektriksel akım yardımıyla esteraz enzimlerinin jelde tutunmasını sağlamak amacıyla koşturma işlemi $150 \mathrm{~V}$ 'da yapılmıştır. Elektroforez jelleri \%0.02'lik $\alpha$-naphthyl asetat içeren substrat solüsyonunda esteraz enziminin jel üzerinde tutunabilmesi için $30 \mathrm{dk}$ bekletilmiştir. Bu süre sonunda jeller $\% 0.4$ oranında fastblue BB salt boya içeren solüsyonda esteraz enzimlerinin jel üzerinde görünür hale gelebilmesi için 1 saat süreyle bırakılmıştır. Boyama işleminden sonra jeller parlaklık kazanması amacıyla \%7'lik asetik asit çözeltisi içerisinde bekletilmiştir. Elektroforez jelleri 24 saat sonra çözeltiden alınarak görüntüleme cihazında fotoğrafı çekilmiştir.

\section{Esteraz enziminin kinetik olarak incelenmesi}

Kırmızıörümcek popülasyonlarında esteraz enzim aktivitelerinin sayısal değerlerini belirlemek amacıyla Stumpf\&Nauen (2002) yöntemi uygulanmıştır. T. urticae popülasyonlarının her biri için 20 adet ergin dişi birey $100 \mu \mathrm{l}$ sodyum fosfat buffer içinde plastik ezici yardımıyla homojenize edilmiştir. Esteraz enziminin kinetik okumasının yapılabilmesi için mikroplakanın hücrelerine $25 \mu \mathrm{l}$ homojenat $+25 \mu \mathrm{l}$ fosfat buffer $(0.2 \mathrm{M}, \mathrm{pH}: 6)$ eklenmiştir. Kinetik okuma işlemine geçilmeden önce hücrelere $200 \mu \mathrm{l}$ substrat solüsyonu (30 mg fast blue RR tuzu içeren $50 \mathrm{ml} 0.2 \mathrm{M}$ sodyum fosfat buffer $+500 \mu \mathrm{l} 100 \mathrm{Mm} \alpha$-naphtylacetate) eklenmiştir. Esteraz enziminin kinetik okuma işlemi $23^{\circ} \mathrm{C}, 450 \mathrm{~nm}$ 'de $10 \mathrm{dk}$ süreyle yapılmıştır.

\section{Toplam protein miktarinin belirlenmesi ve istatistiki değerlendirme}

Esteraz enziminin mikroplaka hücrelerinde yapılan kinetik okumaları dört tekerrürlü olacak şekilde uygulanmıştır. Esteraz enziminin toplam protein miktarlarının belirlenmesinde Bradford (1976)'un toplam protein yöntemi kullanılmıştır. Toplam protein yönteminde Bradford standartı olarak Bovine Serum Albumine (BSA) kullanılmış ve kimyasal Amresco firmasından temin edilmiştir. T. urticae popülasyonlarında esteraz enzimi ve toplam protein miktarlarının analizleri Softmax PRO software programında yapılmış ve sonuçlar mOD min ${ }^{-1} \mathrm{mg}^{-1}$ olarak verilmiştir. Enzim sonuçlarından elde edilen verilere tek yönlü varyans analizi tekniği (One-Way ANOWA) uygulanmış ve popülasyonlar arasındaki esteraz enzim aktivitesi farklılıklarının belirlenebilmesi için Tukey testi kullanılmıştır. 


\section{Araştırma Sonuçları ve Tartışma}

\section{Bioassay test sonuçları}

Tetranychus urticae'nin karanfil seralarından toplanan popülasyonları ve GSS popülasyonunda spirodiclofen'e karşı belirlenen eğim değerleri, $\mathrm{LC}_{50}$ değerleri, güven aralıkları ve sera popülasyonlarında direnç oranları Çizelge 2'de verilmiştir. T. urticae popülasyonlarında spirodiclofen'e karşı belirlenen direnç oranları 30.49-118.78 kat arasında değişmiştir. LC denemelerinden elde edilen eğim sonuçları popülasyonun homojen ya da heterojen yapısı ile ilgili bilgi vermektedir. Buna göre eğim değeri >2 olan popülasyonların daha homojen yapıda olduğu, <2 olan popülasyonların ise daha heterojen yapıda oldukları bilinmektedir (Yu, 2008). Spirodiclofen için yapılan deneme sonucunda eğim değerleri incelendiğinde, 118.78 kat ile en yüksek direnç katına sahip olan K3 popülasyonunda eğim değerinin $>2$ olması nedeniyle popülasyonun diğer popülasyonlara göre daha homojen bir yapıya sahip olduğu değerlendirilmiştir. Oysa ki K1- K2 ve K4 popülasyonlarında eğim değerinin <2 olması sebebiyle popülasyon yapılarının daha heterojen olduğu görülmektedir. Bu durum karanfil seralarında spirodiclofen baskısına devam edilecek olursa bu üç popülasyonda da direnç oranının artacağını göstermektedir. Rauch\&Nauen (2003) ve Van Pottelberge et al. (2009a), T. urticae'de seleksiyon baskısı sonucu spirodiclofene direnç geliştiğini belirtmişlerdir. Van Pottelberge et al. (2009b), spirodiclofenin iki noktalı kırmızı̈rümceklerde larva döneminde öldürücü etki yaptığını, ergin dönemde işe dişilerde bırakılan yumurta sayısını azalttı̆̆ını bildirmişlerdir. Ferreira et al. (2015), gül ve krizantem üzerinden topladıkları abamectin dirençli $T$. urticae popülasyonlarında spirodiclofen karşı 390 ve 400 kat çapraz direnç bulmuşlardır.

Çizelge 2. Tetranychus urticae popülasyonlarında spirodiclofen'e için belirlenen eğim değerleri, LC ${ }_{50}$ değerleri, güven aralıkları ve direnç oranları

\begin{tabular}{|c|c|c|c|c|}
\hline Popülasyon & $\mathrm{N}^{\mathrm{a}}$ & $E_{g}{ }^{\prime}{ }_{ \pm} e^{b}$ & $\begin{array}{l}\mathrm{LC}_{50}\left(\mathrm{mg} \text { a.i. } \mathrm{I}^{-1}\right) \\
(95 \% \mathrm{CL})\end{array}$ & $\mathrm{R}^{\mathrm{c}}$ \\
\hline $\mathrm{K} 1$ & 601 & $1.726 \pm 0.145$ & 59.94 & 31.74 \\
\hline $\mathrm{K} 2$ & 643 & $1.871 \pm 0.165$ & $\begin{array}{l}48.31-72.97 \\
109.51 \\
87.62-133.73\end{array}$ & 58.00 \\
\hline K3 & 610 & $2.326 \pm 0.340$ & $\begin{array}{l}224.27 \\
151.70-290.66\end{array}$ & 118.78 \\
\hline $\mathrm{K} 4$ & 628 & $1.557 \pm 0.134$ & $\begin{array}{l}57.57 \\
30.86-72.36\end{array}$ & 30.49 \\
\hline GSS & 644 & $1.654 \pm 0.194$ & $\begin{array}{l}1.88 \\
1.41-2.39\end{array}$ & - \\
\hline
\end{tabular}

\footnotetext{
${ }^{a}$ Denemedeki toplam Tetranychus urticae sayısı

${ }^{\mathrm{b}}$ Satandart hata

${ }^{c}$ Tetranychus urticae popülasyonlarının direnç katları
}

Tetranychus urticae'nin karanfil seralarından toplanan popülasyonları ve GSS popülasyonunda abamectine karşı belirlenen eğim değerleri, LC $_{50}$ değerleri, güven aralıkları ve direnç oranları Çizelge 3 'de verilmiştir. T. urticae popülasyonlarında abamectine karşı belirlenen direnç oranları 39.76-246.23 kat arasında değişmiştir. İki noktalı kırmızıörümcek popülasyonlarında abamectin için belirlenen eğim değerleri incelendiğinde, K2 popülasyonunun eğim değerinin $>2$ olması nedeniyle homojen bir yapıya sahip olduğu görülmektedir. Ancak K1, K3 ve K4 popülasyonlarının eğim değerlerinin <2 olması popülasyonların daha heterojen bir yapıda olduğunu göstermektedir. Bu durum K1, K3 ve K4 popülasyonları üzerindeki abamectin seleksiyon baskısı devam ettikçe bu popülasyonlarda abamectin direncinin artma olasılığının yüksek olduğu anlamına gelmektedir. T. urticae'de abamectine karşı yüksek oranda direnç gelişimi birçok çalışmada bildirilmiştir ( Campos et al., 1995; Nicastro et al., 2010; Khajehali et al., 2011). Campos et al. (1996) hibiskus ve gül bitkilerinden topladıkları iki noktalı kırmızıörümcek popülasyonlarında 47 ve 84 kat abamectin direnci bulmuşlardır. Beers et al. (1998) T. urticae'de 27 kat abamectin direnci belirlemişlerdir. Tirello et al. (2012) kesme çiçek olan gül bitkisi üzerinden topladıkları T. urticae'de 1294.1 kat abamectin direnci belirlemişlerdir. Çalışmamızda da benzer şekilde kesme çiçek olan karanfil bitkisinden toplanan popülasyonlarda abamectin direnci belirlenmiştir. Ayrıca T. urticae popülasyonlarında abamectin direnci spirodiclofen direncine göre daha yüksek bulunmuştur. Bu durumun abamectinin daha uzun süre $T$. urticae mücadelesinde kullanılmasından kaynaklandığı düşünülmektedir. Nauen et al. (2000) spirodiclofen dirençli $T$. urticae'de abamectine karşı çapraz direnç geliştiğini bildirmiştir. Çalışmamızda karanfil seralarından toplanan kırmızıörümcek popülasyonlarında abamectin ve spirodiclofen direncinin birlikte oluşması bu durumu açıklamaktadır. 
Çizelge 3. Tetranychus urticae popülasyonlarında abamectin için belirlenen eğim değerleri, LC $_{50}$ değerleri, güven aralıkları ve direnç oranları

\begin{tabular}{|c|c|c|c|c|}
\hline Popülasyon & $\mathrm{N}^{\mathrm{a}}$ & $E_{g ̆ i m} \pm s e^{b}$ & $\begin{array}{l}\mathrm{LC}_{50}\left(\mathrm{mg} \text { a. } \mathrm{I}^{-1}\right) \\
(95 \% \mathrm{CL})\end{array}$ & $R^{c}$ \\
\hline K1 & 600 & $1.857 \pm 0.1 .63$ & 85.00 & 74.49 \\
\hline K2 & 640 & $2.655 \pm 0.650$ & $\begin{array}{l}67.57-103.92 \\
49.67 \\
8.80-192.04\end{array}$ & 43.53 \\
\hline K3 & 620 & $1.501 \pm 0.165$ & $\begin{array}{l}280.95 \\
186.46-393.13\end{array}$ & 246.23 \\
\hline K4 & 618 & $1.274 \pm 0.112$ & $\begin{array}{l}45.37 \\
22.35-65.75\end{array}$ & 39.76 \\
\hline GSS & 644 & $1.401 \pm 0.125$ & $\begin{array}{l}1.14 \\
0.89-1.42\end{array}$ & - \\
\hline
\end{tabular}

${ }^{a}$ Denemedeki toplam Tetranychus urticae sayısı

${ }^{\mathrm{b}}$ Satandart hata

${ }^{\mathrm{C}}$ Tetranychus urticae popülasyonlarının direnç katları

\section{Biyokimyasal sonuçlar}

\section{Poliakrilamid jel elektroforez sonuçları}

Karanfil seralarından toplanan T. urticae popülasyonları ve GSS popülasyonunun elektroforez jelleri üzerinde görüntülenen esteraz enzim bantları Şekil 1'de verilmiştir.

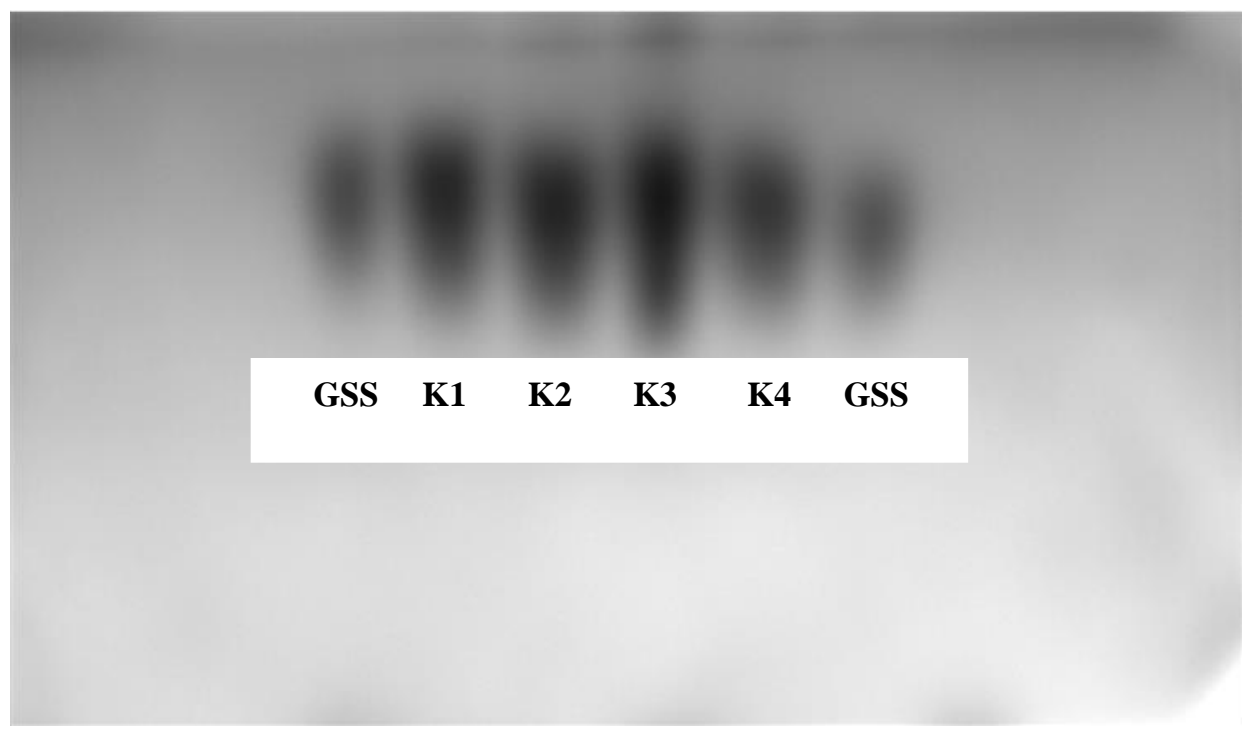

Şekil 1. Tetranychus urticae popülasyonlarının elektroforez jellerinde görüntülenen esteraz enzim bantları.

Tüm iki noktalı krımızı̈rümcek popülasyonlarının elektroforez jelleri üzerinde görüntülenen esteraz bantları incelendiğinde, karanfil seralarından toplanan K1, K2, K3 ve K4 popülasyonlarına ait esteraz bant yoğunluklarının GSS popülasyonuna ait esterazbant yoğunluğuna göre daha fazla olduğu belirlenmiştir. Karanfil seralarından toplanan $T$. urticae popülasyonları arasında ise esteraz özellikle K3 popülasyonuna ait bantın en yoğun olduğu görülmektedir.

\section{Esteraz enzimi kinetik okuma sonuçları}

Tetranychus urticae popülasyonlarının mikroplaka hücrelerinde kinetik okuma sonucu belirlenen esteraz enzim aktivitesi sonuçları Çizelge 4'de verilmiştir. Esteraz enzim aktivitesi sonuçları incelendiğinde, karanfil seralarından toplanan kırmızıörümcek popülasyonlarının esteraz enzim aktivitelerinin sayısal değerlerinin GSS popülasyonuna göre yüksek bulunduğu görülmektedir. $T$. urticae popülasyonlarında esteraz enzim aktivitesinin

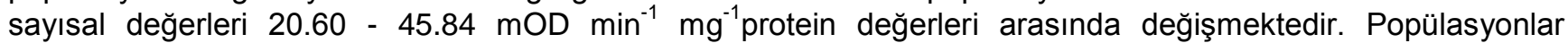




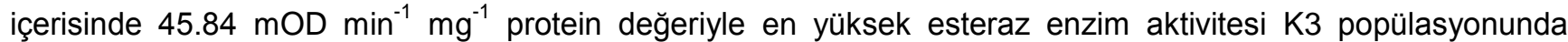
belirlenmiştir. K3 popülasyonu diğer popülasyonlarla karşılaştııılığında istatistiki olarak faklı bir grupta ifade edilmiştir $(\mathrm{P}<0.05)$. K1 ve K2 popülasyonlarının esteraz enzimlerinin sayısal değerleri benzer bulunmuş ve iki popülasyon istatistiki olarak aynı grup içerisinde yer almıştır $(P<0.05)$. Kinetik okuma sonucu elde edilen esteraz enzim aktivitesi sayısal değer sonuçları ve elektroforez jellerinde belirlenen esteraz enzim bant görüntüleri birbiri ile uyuşmaktadır. Çünkü karanfil seralarından toplanan popülasyonlarının tamamında esteraz enziminin hem sayısal değerleri hem de bant yoğunlukları GSS popülasyonuna göre yüksek bulunmuştur.

Tetranychus urtica 'de akarisitlere karşı gelişen dirençle esteraz enzim bağlantısını açıklayan birçok çalışma bulunmaktadır (Van Leeuwen \& Tirry, 2007;Yang et al., 2002; Mogdaham et al., 2012). Özellikle iki noktalı kırmızı̈rümcekte abamectin ve spirodiclofen direncinin gelişmesinde esteraz enziminin etkili olduğunu gösteren çalışmalar da mevcuttur. Stumpf\&Nauen (2002) abamectin dirençli $T$. urticae popülasyonunda 1.6 kat esteraz enzim aktivitesi belirlemişlerdir. Rauch \& Nauen (2003) gül bitkisi üzerinden toplanan spirodiclofen dirençli $T$. urticae'de spirodiclofen direnç gelişiminde esteraz enziminin rol oynadığını bildirmişlerdir. Pottelberge et al. (2009) 274 kat spirodiclofen dirençli $T$. urticae popülasyonunda esteraz ve enziminin direnç gelişiminde rol oynadığını belirlemişlerdir. Çalışmamızda da $T$. urticae'nin karanfil seralarından toplanan tarla popülasyonlarında abamectin ve spirodiclofen akarisitlerine karşı gelişen dirençte esteraz enziminin büyük öneme sahip olduğu düşünülmektedir. Biyokimyasal çalışmalar içerisinde yer alan hemelektroforez yöntem hem de kinetik okuma sonuçları da esteraz enziminin karanfil seralarından toplanan kırmızıörümcek popülasyonlarındaki direnç gelişimine etkisi olabileceği kanısını güçlendirmektedir. Özellikle her iki akarisite karşı en yüksek oranda direnç belirlenen 3 numaralı popülasyonda esteraz enzim aktivitesinin diğer popülasyonlara göre en yüksek bulunması da bu görüşü desteklemektedir.

Çizelge 4. Tetranychus urticae popülasyonlarında kinetik okuma sonucu belirlenen esteraz enzim aktiviteleri

\begin{tabular}{cccc}
\hline Popülasyon & $\mathrm{n}^{*}$ & $\begin{array}{c}\text { Spesifik aktivite } \\
\mathrm{mOD} \mathrm{min}^{-1} \mathrm{mg}^{-1} \text { protein }\end{array}$ & $\mathrm{R} / \mathrm{S}^{\star *}$ \\
\hline GSS & 4 & $10.22 \mathrm{~d}^{\star \star *}$ & \\
1 & 4 & $32.25 \mathrm{~b}$ & 3.15 \\
2 & 4 & $30.38 \mathrm{~b}$ & 2.97 \\
3 & 4 & $45.84 \mathrm{a}$ & 4.48 \\
4 & 4 & $20.60 \mathrm{c}$ & 2.01 \\
\hline
\end{tabular}

\footnotetext{
* Tekerrür sayısı

** Denenen popülasyonun enzim aktivitesi/ hassas popülasyonun enzim aktivitesi

${ }^{* * \star A y n ı ~ h a r f l e r ~ i s t a t i s t i k i ~ o l a r a k ~ a y n ı ~ g r u b u ~ g o ̈ s t e r m e k t e d i r ~}(P<0.05)$
}

Sonuç olarak, abamectin ve spirodiclofen akarisitlerine karşı karanfil seralarından toplanan $T$. urticae popülasyonlarından bazılarında orta düzeyde direnç belirlenirken, özellikle 3 numaralı popülasyonda yüksek oranda direnç bulunmuştur. K3 popülasyonunda yüksek esteraz enzim aktivitesinin bulunması abamectin ve spirodiclofen direnciyle esteraz enziminin ilişkili olabileceğini göstermektedir. Bu çalışma sonucuna göre, Isparta ili Merkez ilçe karanfil seralarında kırmızıörümceklere karşı yaygın olarak kullanılan iki akarisitin $T$. urticae popülasyonunlarında önemli bir duyarlılık kaybına neden olduğu görülmektedir. Karanfil seralarında $T$. urticae'de gelişen abamectin ve spirodiclofen akarisit direnç yönetimini sağlayabilmek için farklı etki mekanizmasına sahip akarisitlerle rotasyona sokulmaları gerektiği düşünülmektedir.

\section{Teşekkür}

2209-A Üniversite Öğrencileri Yurt İçi Araştırma Projeleri Destek Programı ile çalışmayı maddi olarak destekleyen Türkiye Bilimsel ve Teknik Araştırmalar Kurumu (TÜBiTAK-TOVAG)'a teşekkür ederiz. 


\section{Yararlanılan Kaynaklar}

Anonymous, 2016. T.C. Başbakanlık Türkiye İstatistik Kurumu Başkanlığı, Ankara. (Web sayfası: http://www.tuik.gov.tr.) (Erişim tarihi: Haziran, 2014).

Bolland, H.H., J. Gutierrez \& C.H.W. Flechtmann, 1998. World Catalogue of the Spider Mite Family (Acari: Tetranychidae). Brill, Leiden.

Bradford, M.M., 1976. A rapid and sensitiv method for the quantitation of microgram quantities of protein utilizing the principle of protein - dye inding. Analytical Biochemistry, 72: 248-254.

Campos, F., R.A., Dybas \& D.A. Krupa, 1995. Susceptibility of two spotted spider mite (Acari: Tetranychidae) populations in California to abamectin. Journal of Economic Entomology, 88: 225-231.

Campos, F., D.A. Krupa \& R.A. Dybas, 1996. Susceptibility of populations of two spotted spider mites (Acari: Tetranychidae) from Florida, Holland, and the Canary Islands to abamectin and characterization of abamectin resistance. Journalof EconomicEntomology, 89: 594-601.

Ferreira, C.B.S., F.H.N. Andrade, A.R.S. Rodrigues, H.A.A. Siqueira \& M.G.C. Gondim Jr., 2015. Resistance in field populations of Tetranychus urticae to acaricides and characterization of the inheritance of abamectin resistance. Crop Protection, 67: 77-83.

Feyereisen, R., 1995. Molecular biology of insecticide resistance. Toxicology Letters, 82/83: 83-90.

Goka, K. \& A. Takafuji, 1992. Enzyme variations among Japanese populations of the two-spotted spider mites, Tetranychus urticae Koch. Applied Entomology Zoology, 27: 141-150.

Grbic, M., T. Van Leeuwen, R.M. Clark, S. Rombauts, P. Rouze, V. Grbic, E.J. Osborne, W. Dermauw, P.C.T. Ngoc, F. Ortego, P.H. Crespo, I. Diaz, M. Martinez, M. Navajas, E. Sucena, S. Magalhaes, L. Nagy, R.M. Pace, S. Djuranovic, G. Smagghe, M. Iga, O. Christiaens, J.A. Veenstra, J. Ewer, R.M. Villalobos, J.L. Hutter, S.D. Hudson, M. Velez, S.V. Yi, J. Zeng, A.P. daSilva, F. Roch, M. Cazaux, M. Navarro, V. Zhurov, G. Acevedo, A. Bjelica, J.A. Fawcett, E. Bonnet, C., Martens, G., Baele, L., Wissler, A.S.,Rodriguez, L., Tirry, C., Blais, K., Demeestere, S.R., Henz, T.R., Gregory, J. Mathieu, L. Verdon, L. Farinelli, J. Schmutz, E.E. Lindquist, R. Feyereisen \& Y.V. Pee, 2011. Thegenome of Tetranychus urticae reveals herbivorous pest adaptations. Nature 479: 487-492.

Jepson, L.R., H.H. Keifer \& E.W. Baker, 1975. Mites Injurious to Economic Plants. California. University to California Press, $611 \mathrm{pp}$.

Khajehali, J., P. Van Nieuwenhuyse, P. Demaeght, L. Tirry \& T. Van Leeuwen, 2011. Acaricide resistance and resistance mechanisms in Tetranychus urticae populations from rose greenhouse in the Netherlands. Pesticide Managament Science, 67: 1424-1433.

LeOra Software, 1994. Polo-pc: a user' s guide to probit or logit analysis leora software, Berkeley, pp: 28.

Mogdaham, M.M., M. Ghadamyaria \& K. Talebi, 2012. Resistance mechanisms to fenazaquin in Iranian populations of two-spotted spider mite, Tetranychus urticae Koch (Acari: Tetranychidae). International Journal of Acarology, 38 (2): 138-145.

Nicastro, R.L., M.E. Sato \& M.Z. Silva, 2010. Milbemectin resistance in Tetranychus urticae (Acari: Tetranychidae): selection, stability and cross-resistance to abamectin. Experimental and Applied Acarology, 50: 231-241.

Pottelberge S.V., T.V. Leeuwen, J. Khajeali \& L. Tirry, 2009. Genetic and biochemical analysis of a laboratory-selected spirodiclofen-resistant strain of Tetranychus urticae Koch (Acari:Tetranychidae). Pest Management Science, 65: 358-366.

Rauch, N \& R. Nauen, 2003. Spirodiclofen resistance risk assessment in Tetranychus urticae (Acari: Tetranychidae): a biochemical approach. Pesticide Biochemistry and Physiology, 74: 91-101.

Nauen, R., N. Stumpf \& A. Elbert, 2000. Efficacy of BAJ 2740, a new acaricidal tetronicacid derivative, against tetranychid spider mite species resistant to conventional acaricides. Proc Brighton Crop Prot Conf - Pests and Diseases, Vol. 4. British Crop Protection Council, Alton, Hants, UK, pp. 453-458.

Stumpf, N \& R. Nauen, 2002. Biochemical markers linked to abamaectin resistance in Tetranychus urticae (Acari: Tetranychidae). Pesticide Biochemical and Physiology, 72: 111-121.

Tirello, P., A. Pozzebon, S. Cassanelli, T. Van Leeuwen \& C. Duso, 2012. Resistance to acaricides in Italian strains of Tetranychus urticae: toxicological and enzymatic assays. Experimental and Applied Acarology, 57(1): 53-64.

Van Leeuwen, T \& L. Tirry, 2007. Esterase-mediated bifenthrin resistance in a multiresistant strain of the two-spotted spider mite, Tetranychus urticae. Pest Mnagement Science, 63:150-156.

Van Leeuwen, T., J. Vontas, A. Tsagkarakou, W. Dermauw \& L. Tirry, 2010. Acaricide resistance mechanisms in the twospottedspider mite Tetranychus urticae and other important Acari: a review. Insect Biochemical Molecular Biology, 40: 563-572. 
Van Pottelberge, S., J. Khajehali \& T. Van Leeuwen, 2009a. Effects of spirodiclofen on reproduction in a susceptible and resistant strain of Tetranychus urticae (Acari: Tetranychidae). Experimental and Applied Acarology, 47: $301-309$.

Van Pottelberge, S., T. Van Leeuwen \& J. Khajehali, 2009b. Genetic and biochemical analysis of a laboratory-selected spirodiclofen-resistantstrain of Tetranychus urticae Koch (Acari: Tetranychidae). Pesticide Managament Science, 65: 358-366.

Yang, X., L.L., Buschman, K.Y. Zhu \& D.C. Margolies, 2002. Susceptibility and detoxifying enzyme activity in two spider mite species (Acari: Tetranychidae) after selection with three insecticides. Journal of Economic Entomology, 95 (2): 399 406.

Yu, SJ., 2008. The toxicology and biochemistry of insecticides. CRC Pres Taylor- Francis Group, $250 \mathrm{pp}$. 